\title{
ZARZADZANIE ZBIORAMI NOWOCZESNEJ BIBLIOTEKI NAUKOWEJ - RÓWNOWAGA TRADYCJI I NOWOCZESNYCH TRENDÓW
}

\section{Wstęp}

Racjonalne gromadzenie zbiorów tradycyjnych i elektronicznych, przy niedoborach finansowych bibliotek naukowych jest wyjątkowym problemem obecnych czasów. Dyrektorzy bibliotek i kierownicy działów gromadzenia, stają nierzadko przed trudnym wyborem między zakupem nowych baz danych, źródeł elektronicznych czy tradycyjnych zbiorów drukowanych. Statystyki wykorzystywania zarówno zbiorów elektronicznych jak również drukowanych często są niesatysfakcjonujące w stosunku do poniesionych kosztów. W artykule podjęte zostaną rozważania nad efektywną polityką gromadzenia i zarządzania, a zwłaszcza promocją zbiorów bibliotecznych.

\section{Współczesne trendy w polityce gromadzenia}

W ciągu minionych 15 . lat XXI stulecia nastąpiła diametralna zmiana w polityce gromadzenia zbiorów, polegająca na zakupie głównie kolekcji książek i czasopism w wersji elektronicznej objętych licencjami warunkującymi czas, sposób i zakres udostępniania. Zbiory te nie są inwentaryzowane, czyli nie stanowią majątku biblioteki i nie są przechowywane w bibliotece. Stosując politykę zakupu pakietów, uczestnicząc w konsorcjach, a także równolegle pozyskując do zbiorów wydawnictwa drukowane i elektroniczne, biblioteki naukowe powodują, że kolekcje biblioteczne rosną i rozwijają się dziś szczególnie dynamicznie. Dzieje się tak mimo ograniczeń finansowych i braku stabilności finansowej ${ }^{1}$. Rozwój cyfrowych zbiorów stopniowo wymusza zmiany w sposobie myślenia i realizacji

* Urszula Poślada - mgr bibliotekoznawstwa i informacji naukowej, kustosz dyplomowany, zastępca dyrektora Biblioteki Głównej UMCS, e-mail: u.poslada@umcs.lublin.pl

${ }^{1} \mathrm{~J}$. Stępniak, Polityka gromadzenia zbiorów elektronicznych - od samofinansowania do licencji krajowych, w: Biblioteka w kryzysie czy kryzys w bibliotece. Łódź, 15-17 czerwca 2010. Materiały Konferencyjne, Łódź 2010 r., s.83 
procesu gromadzenia zbiorów w bibliotekach akademickich. Oczywiście zakres tematyczny, wartość merytoryczna, przeznaczenie czytelnicze, formy piśmiennicze i wydawnicze, liczba egzemplarzy czy aktualność zasobów - to elementy, które są podstawą budowy i uzupełniania każdej kolekcji bibliotecznej. Opis tych elementów, wyznaczenie priorytetów i wytyczenie realizowanych celów w zakresie budowy kolekcji łącznie tworzy politykę gromadzenia zbiorów. Jednak o ile w odniesieniu do zbiorów tradycyjnych realizacja polityki gromadzenia przede wszystkim opiera się na środkach własnych jednostki, o tyle zakup zasobów elektronicznych głównie dofinansowywany jest ze środków zewnętrznych. Stwarza to odrębną jakość, gdyż z jednej strony umożliwia znaczące rozszerzenie oferty biblioteki, a z drugiej strony sprawia, że jej samodzielność w podejmowaniu decyzji o profilu zbiorów i wyborze konkretnych tytułów tworzących jej kolekcje jest w znacznym stopniu ograniczona ${ }^{2}$. Gromadzenie czy też tworzenie zasobów nowoczesnej biblioteki akademickiej, jak wskazuje już kilkunastoletnie doświadczenie bibliotek uczelnianych, nie może być nadmiernie nastawione tylko i wyłącznie na elektroniczne formy zbiorów, nie może opierać się głównie na nowinkach technologicznych, które wprawdzie zdejmują $\mathrm{z}$ bibliotekarzy wiele codziennych, żmudnych obowiązków związanych z opracowaniem zbiorów czy z przygotowaniem ich do udostępnienia, ale w dalszej perspektywie okazują się mało efektywne zarówno dla procesu dydaktycznego, w jakim uczestniczy biblioteka akademicka, jak również dla polityki gromadzenia i kształtowania kolekcji bibliotecznej. Zbiory elektroniczne są zbiorami ulotnymi, efemerycznymi. Ich zmienność zależy zarówno od kondycji finansowej biblioteki prenumerującej czy licencjonującej dane bazy czy kolekcje pełnotekstowe, jak również od umów wydawniczych i licencyjnych.

Biblioteki naukowe, w szczególności biblioteki szkół wyższych, tworzą kolekcje biblioteczne zgodnie z długofalowymi celami i potrzebami jednostek macierzystych, uwzględniając przede wszystkim ich bieżące potrzeby. Strategiczne decyzje, które dziś podejmuje bibliotekarz, dotyczą nie tylko tego, czy włączyć konkretny tytuł do zbiorów, ale też w jakiej formie będzie on najbardziej przydatny czytelnikom (wersja drukowana, elektroniczna czy obie); czy dążyć do specjalizacji zbiorów, czy też zmierzać do poszerzenia zakresu merytorycznego (celowego lub wymuszonego ofertą dostawców pakietów). Nowe warunki techniczne sprawiają, że istotna staje się kwestia możliwości udostępniania w bibliotece zbiorów, które nie są jej własnością (w Internecie), albo są oferowane na zasadach licencyjnych (na czas określony). Jeśli jednak biblioteka decyduje się na zakup, to czy powinna gwarantować wieczystą archiwizację nabytych treści? Jakie będą tego koszty i czy ta archiwizacja jest rzeczywiście potrzebna i w praktyce możliwa ${ }^{3}$. Biblioteki powinny zatem określić w jakim stopniu wydawnictwa elektroniczne uzupełniają zbiory biblioteczne, a które z nich są tylko udostępniane i nie stanowią własności bibliotecznej.

\footnotetext{
${ }^{2}$ Tamże, s. 71.

${ }^{3}$ Tamże, s.73.
} 
Wypracowanie polityki gromadzenia w bibliotece naukowej, to umiejętność dostosowania strategii działania do zmieniających się okoliczności, co oznacza analizę zawartości elektronicznych baz danych biblioteki, niezbędną dla określania stanu udostępnianych zasobów i zapotrzebowania na tytuły drukowane oraz inne bazy danych. Wydaje się, że najwyższa pora, aby zaktualizować zasady ewidencji zbiorów bibliotecznych i uwzględnić w nich sposób ewidencji kolekcji dostępnych w ramach licencji. Szczególnie, jeśli taka licencja ma charakter wieloletni i w istotny sposób uzupełnia jej zbiory. Podobny problem dotyczy zasobów naukowych i edukacyjnych otwartego Internetu. Pomijanie obu tych typów usług w kategorii „zbiory biblioteczne” może w istotny sposób zubożyć i zniekształcić rzeczywisty obraz treści merytorycznych oferowanych przez bibliotekę. Zatem zarówno zakup licencji, jak i udostępnianie zbiorów otwartego Internetu stanowią kategorie, które powinny być zdefiniowane w polityce gromadzenia (np. w jakim procencie mogą one stanowić bieżące uzupełnienie zbiorów, jakiej kategorii zbiorów dotyczyć) $)^{4}$. Zakup materiałów bibliotecznych skupia sie głownie na nowościach wydawniczych. Ze względu na najczęściej niewielkie nakłady finansowe, pozyskiwane są jedynie najważniejsze dla działalności bibliotek pozycje. Zakup książek lub prenumerata czasopism, dokonywane są na potrzeby konkretnych czytelników, a czynnikiem decydującym o zakupie danego tytułu są potrzeby czytelnicze ${ }^{5}$.

\section{Zarządzanie licencjonowanymi zbiorami elektronicznymi}

W zakres polityki zarządzania zbiorami wchodzą: celowość kształtowania zbiorów, zakres księgozbioru oraz jego zawartość i sposób dostępu do niego z zewnątrz. Jak pisze na łamach „Forum Książki” Henryk Holender w artykule: Gromadzenie po macoszemu:

Nasz pierwszy, podstawowy, intuicyjny ogląd biblioteki polega na stwierdzeniu, czy ma ona „dobre zbiory”. Łatwiej zresztą orzec, że zbiory dobre nie są - zwyczajowo konstatujemy to, dostrzegając wśród dostępnych w bibliotece materiałów niewybaczalne luki. Żeby natomiast zbiory ocenić pozytywnie, nie wystarczy dokonać kilku korzystnych znalezisk. Trzeba umieć wyobrazić sobie grupę użytkowników biblioteki i opisać jej potrzeby w kategoriach bibliotecznego stanu posiadania. Stan ten wyraża inwentarz i katalog, ale także układ systematyczny, który ujawnia proporcje ilościowe pomiędzy poszczególnymi grupami piśmiennictwa ${ }^{6}$.

Niestety, jak już zostało to wspomniane, zbiory elektroniczne w przeważającej większości nie są inwentaryzowane ani katalogowane, stąd też na ogół nie brane są pod uwagę w ocenie zbiorów bibliotecznych. Stanowi to oczywisty błąd, ale przy dotychczasowych standardach ewidencji księgozbioru stan taki będzie trwał jeszcze jakiś czas. Stąd też przed biblioteką akademicką wyrasta podstawowe zadanie dotyczące funkcjonalnego zarządzania licencjonowanymi zbiorami elektronicznymi i ich permanentną promocją. Zarządzanie nieinwentaryzowany-

\footnotetext{
${ }^{4}$ Tamże, 74.

${ }^{5}$ L. Biliński, Prawo biblioteczne na co dzień, Warszawa 2006, s. 99.

${ }^{6}$ H. Holender, Gromadzenie po macoszemu, „Forum Książki”, 43 (2009) nr 1, s. 6
} 
mi zborami elektronicznymi powinno oczywiście w głównej mierze opierać się na szczegółowej analizie statystyk wykorzystywania baz danych. Niestety statystyki oferowane przez wydawców baz elektronicznych czy kolekcji pełnotekstowych często są niejednolite i co najważniejsze niejednoznaczne. W wypadku Biblioteki Uniwersytetu Marii Curie-Skłodowskiej wydaje się, że problem ujednolicenia statystyk został przynajmniej częściowo rozwiązany, gdyż w tym celu wykorzystywane są statystyki użytkowania źródeł elektronicznych uzyskiwane z funkcjonującego w bibliotece oprogramowania HAN firmy $\mathrm{H}+\mathrm{H}$ Software $\mathrm{GmbH}$. Program HAN, który odnotowuje wszelki ruch w zakresie wprowadzonych do oprogramowania adresów internetowych - oczywiście w wypadku bibliotek są to adresy baz danych i kolekcji pelnotekstowych, dla wygenerowania rzeczywistych i rzetelnych statystyk, wymaga wprowadzenia pełnego zasobu licencjonowanych przez instytucje źródeł elektronicznych. Wymaga również dokładnego zdefiniowania obszarów IP, z których czytelnicy nie muszą logować się w systemie oraz zdefiniowania bazy użytkowników, która będzie służyć do logowania się czytelników spoza campusa oraz nadawania poszczególnym linkom właściwości protokołowania w celach statystycznych. Oczywiście dla rzetelności statystyk użytkownikom nie powinny być udostępniane licencjonowane bazy w inny sposób niż tylko za pośrednictwem programu HAN. Tak uzyskane informacje liczbowe o zainteresowaniu danymi źródłami lub też braku zainteresowania wśród uprawnionych, już wcale nie potencjalnych użytkowników, stają się świetnym narzędziem do zarządzania prenumeratą $\mathrm{w}$ zakresie danych licencji. Statystyki dają możliwość analizy grup czytelniczych zainteresowanych oferowanymi zbiorami. Taka analiza może skutkować nawiązaniem kontaktów np. z grupą pracowników naukowych korzystających ze źródeł elektronicznych czy grupą najaktywniejszych studentów. Do nich mogą być wysyłane zarówno oferty nowych źródeł elektronicznych, jak również informacje o nowościach bibliotecznych. Można też próbować nawiązywać $\mathrm{w}$ ten sposób współpracę przy rozwijaniu w bibliotece zasobów zarówno drukowanych jak i elektronicznych. Dogłębne przestudiowanie statystyk wykorzystania oferowanych baz i kolekcji elektronicznych pozwala również opracować skuteczną politykę promocji zbiorów.

\section{Zbiory - promocja, dydaktyka i organizacja}

Prowadzone już od kilku lat, czy to przez uczelnie czy biblioteki, dość systematyczne badania czytelnictwa studentów i ich satysfakcji czytelniczej z oferowanych przez biblioteki zbiorów i usług przedstawiają podobne wyniki. Analizy odpowiedzi ankietowych wykazują, że zbiory elektroniczne są mniej doceniane niż zbiory tradycyjne przez największą grupę użytkowników bibliotek akademickich, czyli studentów. Najprawdopodobniej ocena ta wynika ze słabo rozwiniętych umiejętności informacyjnych u młodych ludzi. Tak naprawdę korzystania z baz elektronicznych należy się nauczyć. Umiejętności trafnego zadawania pytania za pomocą słów kluczowych, szybkiej oceny przeszukiwanego źródła, skutecznej selekcji znalezionego materiału nie jest sztuką łatwą. Stąd też częste zniechęcenie młodzieży, gdy okazuje się, że bazy elektroniczne w łatwy i szybki sposób nie zaspakajają potrzeb badawczych. I w tym punkcie również w ramach 
zarządzania zbiorami biblioteki kształtuje się dla bibliotek szeroko pojęte zadanie szkoleniowo-dydaktyczne i promocyjne. Kształtowanie umiejętności informacyjnych zwłaszcza w zakresie oferty bibliotecznej powinno obejmować nie tylko użytkowników, czytelników ale również bibliotekarzy. Efektywne zarządzanie a przez to wykorzystanie zbiorów bibliotecznych, w tym o wiele trudniejszych do ogarnięcia zbiorów elektronicznych jest nie możliwe bez zaangażowania całego personelu bibliotecznego. Bibliotekarze różnych oddziałów jak również bibliotek specjalistycznych wchodzących w struktury biblioteki akademickiej powinni a nawet wręcz muszą orientować się w zasobach drukowanych i elektronicznych, gdyż obecnie, jak właściwie nigdy dotąd nie było tak zintegrowanego systemu pracy. Wszelkie działania w zakresie zarządzania zbiorami począwszy od gromadzenia przez opracowanie, organizację dostępu, udostępnianie, ochronę, ewidencję, skontrum i selekcje oparte są na znajomości pełnego zasobu bibliotecznego, zarówno tradycyjnego, jak i w głównej mierze uzupełniającego go elektronicznego. Bibliotekarze nie rozwijający własnych umiejętności informacyjnych w zakresie oferowanych przez bibliotekę zbiorów elektronicznych stają się „niemi” w dialogu z użytkownikiem, nie są w stanie przedstawić czytelnikowi alternatywy w sytuacji braku zbioru tradycyjnego, jak również nie potrafią zaoferować równorzędnych sposobów poszukiwania i korzystania z literatury naukowej. Tak więc promocja i szkolenie w zakresie zasobów elektronicznych jest stałym elementem zarządzania tymi zbiorami.

Jak już zostało to wspomniane wcześniej, w gromadzeniu zbiorów bibliotecznych należ zachować możliwy dystans między budowaniem zasobów tradycyjnych a elektronicznych. Dla skutecznego kształtowania księgozbioru tradycyjnego, jak również dla efektywnego zarządzania nim, służy chociażby organizowanie wolnego dostępu do zbiorów. Głównymi zasadami doboru księgozbioru do wolnego dostępu, organizowanego na przykładzie Biblioteki Głównej UMCS, jest kryterium aktualności literatury, dobór merytoryczny w zakresie reprezentowanej dziedziny jak i formalny. Do wolnego dostępu typowane są najnowsze podręczniki akademickie, najnowsze opracowania wyników badań, monografie naukowe i oczywiście najnowsze słowniki, leksykony i encyklopedie dziedzinowe. Wolny dostęp umożliwia łatwy sposób oceny kompletności najnowszej literatury $\mathrm{z}$ reprezentowanej dziedziny a przez to również ułatwia gromadzenie najpotrzebniejszych zbiorów. Najefektywniej układ taki sprawdza się w zakresie wszystkich dziedzin naukowych reprezentowanych zbiorach bibliotecznych. Nie zawsze jest to możliwe do osiągnięcia, jak chociażby w BG UMCS, gdzie w pełni zostało zorganizowanych dziewięć dziedzin: nauki pomocnicze historii, historia, nauki społeczne (ekonomia, socjologia), nauki polityczne, prawo, wojskowość, dzieła treści ogólnej (wielodziedzinowe encyklopedie, informatory), bibliotekoznawstwo, bibliologia, bibliografie ogólne, informacja naukowa. Pozostałe dziedziny, jak filozofia, religioznawstwo, psychologia, pedagogika, językoznawstwo i literatura, nauki ścisłe i przyrodnicze, medycyna, technika są w przygotowaniu do wolnego dostępu. Statystyki wykorzystywania w ten sposób udostępnianego księgozbioru mają również znaczenie w prowadzeniu racjonalnej polityki gromadzenia zbiorów, gdyż informacja o częstotliwości wykorzystywania danych tytu- 
łów może być pomocna w podejmowaniu decyzji o zwiększeniu przez zakup ilości egzemplarzy czy też o wycofaniu danego nie wykorzystywanego księgozbioru $\mathrm{z}$ obszaru wolnego dostępu. Ta forma udostępniania zbiorów bibliotecznych skutkuje również pozyskiwaniem informacji o zapotrzebowaniach czytelniczych, co może się w miarę możliwości finansowych instytucji przełożyć na skuteczne pro czytelnicze kształtowanie zbiorów.

Zbiory biblioteki generalnie wymagają promocji, ale zwłaszcza wymagają jej zbiory bezpośrednio udostępniane czytelnikowi, jak chociażby w formie wolnego dostępu. Doskonały zabieg promocyjny jak i informacyjny zastosowała Biblioteka Uniwersytetu Przyrodniczego w Lublinie przedstawiając w bazie katalogowej podział księgozbioru wytypowanego do wolnego dostępu według zastosowanej dziedzinowej Klasyfikacji Biblioteki Kongresu. Czytelnik wybierając daną dziedzinę $\mathrm{w}$ fasetach lewego marginesu $\mathrm{w}$ interfejsie katalogowym może przejrzeć całą jej zawartość. Zabieg ten nie tylko służy pobudzaniu zainteresowań czytelniczych, ale również ułatwia zapewnienie kompletności i aktualności danej kolekcji dziedzinowej.

Zarządzanie zbiorami bibliotecznymi w obecnym czasie odbywa się również przez integrację $\mathrm{w}$ internetowym obszarze wszystkich zbiorów prezentowanych przez bibliotekę. Takimi narzędziami służącymi scaleniu informacji o zbiorach są stosowane w bibliotekach różnego rodzaju multiwyszukiwarki. W Lublinie, w trzech bibliotekach uniwersyteckich: KUL, UM i UMCS, w celu integracji zbiorów drukowanych i elektronicznych jest wykorzystywana multiwyszukiwarka PRIMO. I w tym wypadku przed bibliotekarzami odpowiedzialnymi za gromadzenie i udostępnianie wszelkich zbiorów bibliotecznych powstaje nowe zadanie - zarządzanie zasobami udostępnianymi czytelnikowi za pomocą wyszukiwarek naukowych. To jakie wyniki otrzymuje użytkownik wykorzystując do poszukiwań badawczych multiwyszukiwarkę oferowaną przez bibliotekę zależy W głównej mierze od pracy bibliotekarza, od tego jakie zostaną wprowadzone do niej źródła. Bibliotekarz ma obowiązek zarządzać i podejmować decyzje na temat włączenia licencjonowanych czy też $\mathrm{w}$ formie open access baz, załączania prenumeraty czasopism czy książek elektronicznych, czuwania nad właściwym importowaniem metadanych dotyczących zbiorów tradycyjnych, drukowanych prezentowanych przez bazę katalogową.

\section{Zakończenie}

Reasumując, obecnie skuteczne zarządzanie zbiorami nowoczesnej biblioteki akademickiej, biblioteki naukowej to zarządzanie pełnym zasobem bibliotecznym drukowanym i elektronicznym, to balansowanie przy zachowaniem równowagi między gromadzeniem względnie trwałych zbiorów drukowanych a zmiennych, dynamicznych zbiorów elektronicznych, to umiejętne, satysfakcjonujące użytkownika udostępnianie zbiorów i ich nieustająca promocja.

Słowa kluczowe: Biblioteka UMCS, biblioteka uniwersytecka, zarządzanie, multiwyszukiwarki, bazy wiedzy 


\title{
BIBLIOGRAFIA
}

Biliński Lucjan, Prawo biblioteczne na co dzień, Warszawa 2006.

Holender Henryk, Gromadzenie po macoszemu. „Forum Książki”, 43 (2009) nr 1, s. 6Stępniak Jolanta, Polityka gromadzenia zbiorów elektronicznych - od samofinansowania do licencji krajowych, w: Biblioteka w kryzysie czy kryzys w bibliotece. Łódź, 15-17 czerwca 2010. Materiały Konferencyjne, Łódź 2010 r.

Szulc Jolanta, Zarządzanie finansami w instytucji non-profit problemy i wyzwania. „FIDES - Biuletyn Bibliotek Kościelnych”, 30-31 (2010) nr 1-2, s. 81-99.

\section{MANAGING THE COLLECTIONS OF A MODERN RESEARCH LIBRARY - A BALANCE BETWEEN TRADITION AND MODERN TRENDS}

\begin{abstract}
Summary
The effective management of the collections of a modern academic library, a research library involves managing the full library collection: both printed and electronic one; maintaining the proper balance between the accumulation of the relatively permanent printed collections and variable, dynamic electronic ones; it also means making collections accessible in the way that satisfies the user and promoting them relentlessly.
\end{abstract}

Keywords: Maria Curie-Skłodowska University (UMCS) Library, a university library, metasearch engines, knowledge bases 